\title{
Continuous and discontinuous variation in ecosystem carbon stocks with elevation across a treeline ecotone
}

\author{
J. D. M. Speed ${ }^{1}$, V. Martinsen ${ }^{2}$, A. J. Hester ${ }^{3}$, Ø. Holand ${ }^{4}$, J. Mulder ${ }^{2}$, A. Mysterud ${ }^{5}$, and G. Austrheim ${ }^{1}$ \\ ${ }^{1}$ University Museum, Norwegian University of Science and Technology, 7491 Trondheim, Norway \\ ${ }^{2}$ Department of Environmental Sciences, Norwegian University of Life Sciences, PO Box 5003, 1432 Ås, Norway \\ ${ }^{3}$ The James Hutton Institute, Craigiebuckler, Aberdeen AB15 8QH, UK \\ ${ }^{4}$ Department of Animal and Aquacultural Sciences, Norwegian University of Life Sciences, PO Box 5003, 1432 Ås, Norway \\ ${ }^{5}$ Centre for Ecological and Evolutionary Synthesis (CEES), Department of Biosciences, University of Oslo, 0316 Oslo, \\ Norway
}

Correspondence to: J .D. M. Speed (james.speed@vm.ntnu.no)

Received: 4 September 2014 - Published in Biogeosciences Discuss.: 7 November 2014

Revised: 30 January 2015 - Accepted: 17 February 2015 - Published: 12 March 2015

\begin{abstract}
Treelines differentiate vastly contrasting ecosystems: open tundra from closed forest. Treeline advance has implications for the climate system due to the impact of the transition from tundra to forest ecosystem on carbon (C) storage and albedo. Treeline advance has been seen to increase above-ground $\mathrm{C}$ stocks as low vegetation is replaced with trees but decrease organic soil $\mathrm{C}$ stocks as old carbon is decomposed. However, studies comparing across the treeline typically do not account for elevational variation within the ecotone. Here we sample ecosystem $\mathrm{C}$ stocks along an elevational gradient $(970$ to $1300 \mathrm{~m}$ ), incorporating a large-scale and long-term livestock grazing experiment, in the southern Norwegian mountains. We investigate whether there are continuous or discontinuous changes in $\mathrm{C}$ storage across the treeline ecotone, and whether these are modulated by grazing. We find that vegetation $\mathrm{C}$ stock decreases with elevation, with a clear breakpoint between the forest line and treeline above which the vegetation $\mathrm{C}$ stock is constant. $\mathrm{C}$ stocks in organic surface horizons of the soil were higher above the treeline than in the forest, whereas $\mathrm{C}$ stocks in mineral soil horizons are unrelated to elevation. Total ecosystem $\mathrm{C}$ stocks also showed a discontinuous elevational pattern, increasing with elevation above the treeline $\left(8 \mathrm{~g} \mathrm{~m}^{-2}\right.$ per metre increase in elevation), but decreasing with elevation below the forest line $\left(-15 \mathrm{~g} \mathrm{~m}^{-2}\right.$ per metre increase in elevation), such that ecosystem $\mathrm{C}$ storage reaches a minimum between the forest line and treeline. We did not find any effect of short-term (12 years) grazing on the elevational patterns. Our findings
\end{abstract}

demonstrate that patterns of $\mathrm{C}$ storage across the treeline are complex, and should be taken account of when estimating ecosystem $\mathrm{C}$ storage with shifting treelines.

\section{Introduction}

The treeline ecotone separates largely contrasting ecosystems in Arctic and alpine zones. Forests, within which high above-ground biomass contributes strongly to the ecosystem carbon stocks, transition over relatively short distances into alpine or Arctic tundra, within which the ecosystem $\mathrm{C}$ stocks are largely within organic horizons in the soil. Globally, low temperatures have been associated with the elevational limitation of the treeline ecotone (Körner and Paulsen, 2004). However, many treelines are not currently advancing despite a warming climate (52\% of treelines showed advance in a recent meta-analysis; Harsch et al., 2009). This supports the suggestion that other factors limit individual treelines at the regional and local scale (Danby, 2011). In some regions, herbivory (Speed et al., 2010; Cairns and Moen, 2004) and land use (Gehrig-Fasel et al., 2007; Tasser et al., 2007) have been directly linked to the limitation of treelines, and hence decreases in herbivory and the abandonment of land use can drive treeline advance, affecting $\mathrm{C}$ storage (Speed et al., 2014).

The latitudinal and elevational advance of trees and shrubs into tundra ecosystems is one of today's key environmen- 
tal changes (Myers-Smith et al., 2011). Crucially, the advance of shrubs and trees into tundra ecosystems can affect the global climate through changing albedo levels, feeding back to further vegetation change (de Wit et al., 2014; Eugster et al., 2000; Chapin et al., 2000). Shifts between tundra and forest ecosystems can also impact on global climate through changes in ecosystem C balance and stocks (Sjögersten and Wookey, 2009). The above-ground to below-ground ratio in ecosystem $\mathrm{C}$ stocks tends to be higher in forest than in tundra ecosystems (e.g. Hartley et al., 2012). Studies comparing alpine and forest ecosystems suggest that treeline advance onto tundra releases the older $\mathrm{C}$ stored in the organic horizons of the soil (Kammer et al., 2009) which is not fully compensated for by increases in above-ground stocks (Hartley et al., 2012; Sjögersten and Wookey, 2009). However, studies that seek to investigate carbon balances over the treeline ecotone typically focus on comparisons of forest and tundra ecosystems, without reference to the wider elevational pattern. Data for European grasslands and Swiss forest ecosystems indicate a significant increase in soil organic carbon stocks with elevation with a particularly strong increase within organic horizons driven by changes in vegetation input and abiotic limitations to decomposition (Sjögersten et al., 2011). However, there may be a clear discontinuity in plant $\mathrm{C}$ stocks at the treeline boundary due to the tendency for cool environment ecosystems to exist in one of two alternate stable states - forest or tundra - with intermediate cover of trees being less common (Scheffer et al., 2012). There thus remains a need for ecosystem-level assessment across the treeline ecotone to fully distinguish threshold effects at the treeline from general elevational patterns in $\mathrm{C}$ stocks.

Herbivores may affect ecosystems $\mathrm{C}$ stocks due to effects on both above- and below-ground processes (Bardgett and Wardle, 2010); however, the effects may vary with herbivore density. For example, even low ungulate densities can prevent treeline advance (Speed et al., 2010), while soil C stocks in alpine grassland peak at low sheep densities (Martinsen et al., 2011). Overall, herbivores may be expected to maintain soil-dominated ecosystem $\mathrm{C}$ stocks at the expense of above-ground $\mathrm{C}$ if the herbivore densities are kept below a threshold that prevents increased plant activity from stimulating decomposition of tundra soil C stocks (Hartley et al., 2012).

Here we aim to determine the relative effect of elevation from that of the treeline per se on ecosystem $\mathrm{C}$ stocks. To achieve this, we assess ecosystem $\mathrm{C}$ stocks along an elevational gradient spanning the treeline ecotone with a range of elevations within both the forest and alpine zones. We combine this with a grazing experiment in the alpine zone to include an investigation of the effects of different densities of grazing livestock over 11 years on alpine tundra carbon stocks. The alpine tundra studied here is dominated by graminoids and ericaceous shrubs and thus differs from the heath-dominated tundra studied by Hartley et al. (2012) and
Sjögersten and Wookey (2009), with more similarity to that studied by Kammer et al. (2009).

We predict that vegetation carbon stocks would decrease with elevation and be greater in the forest than in the alpine zone, with a sharp boundary at the treeline. We also predict that, due to decreasing rates of decomposition at higher elevations (Sjögersten et al., 2011), the soil carbon stock would be greater with elevation and higher in the alpine zone than in the forest, due to faster cycling of organic matter in forests than non-forest soils (Mills et al., 2014). Since soil C stocks are generally larger than vegetation $\mathrm{C}$ stocks in the southern Scandes mountains (Speed et al., 2014), we predict that the ecosystem $\mathrm{C}$ stock would also be greater in the alpine zone than in the forest, with a smooth decrease across the treeline ecotone. Within the alpine zone we also predict that vegetation $\mathrm{C}$ storage would be greatest when ungrazed, due to the increased establishment of birch (Speed et al., 2010) and the elevational advance of lowland species (Speed et al., 2012) following herbivory release. We also predict that the ecosystem-level C stock would be greatest at low sheep densities due to increased soil C storage (Martinsen et al., 2011).

\section{Methods}

\subsection{Study site}

The study was undertaken along an elevational gradient spanning the Betula pubescens ssp. czerepanovii treeline ecotone, from closed forest to open alpine ecosystems, located in $\mathrm{Hol}$ in the mountains of southern Norway. The elevational gradient ranged from 970 to $1300 \mathrm{~m}$. The site consists of a mountain birch forest grading into the alpine zone, within which is a long-term, large-scale alpine grazing experiment giving the opportunity for us to investigate the impact of grazing in addition to elevation. The sheep grazing experiment comprises three treatments: ungrazed $\left(0\right.$ sheep $\left.\mathrm{km}^{-2}\right)$, low $\left(25\right.$ sheep $\left.\mathrm{km}^{-2}\right)$ and high (80 sheep $\mathrm{km}^{-2}$ ) sheep densities across 9 enclosures $(n=3$, in a randomised block design). The enclosures cover an elevational gradient from a minimum of 1050 to over $1300 \mathrm{~m}$ (Fig. 1). The site has been experimentally grazed since 2002 . Prior to the start of the experimental grazing, there was a low density of sheep in the region, so the low-sheep-density treatment represents a continuation of the past grazing history.

The forest line (or timberline sensu Körner and Paulsen, 2004) reaches a maximum at around $1100 \mathrm{~m}$, whilst the current treeline is between 1150 and $1200 \mathrm{~m}$ (Fig. 1). Within the grazing experiment area, sheep have been observed to constrain the establishment and growth of mountain birch at both high and low densities (Speed et al., 2010, 2011a; Speed et al., 2011b). In the ungrazed treatment, birch have recruited across the whole elevational range of the experiment, up to $1300 \mathrm{~m}$ during the experimental grazing period to date (Speed et al., 2010, Fig. 1). 


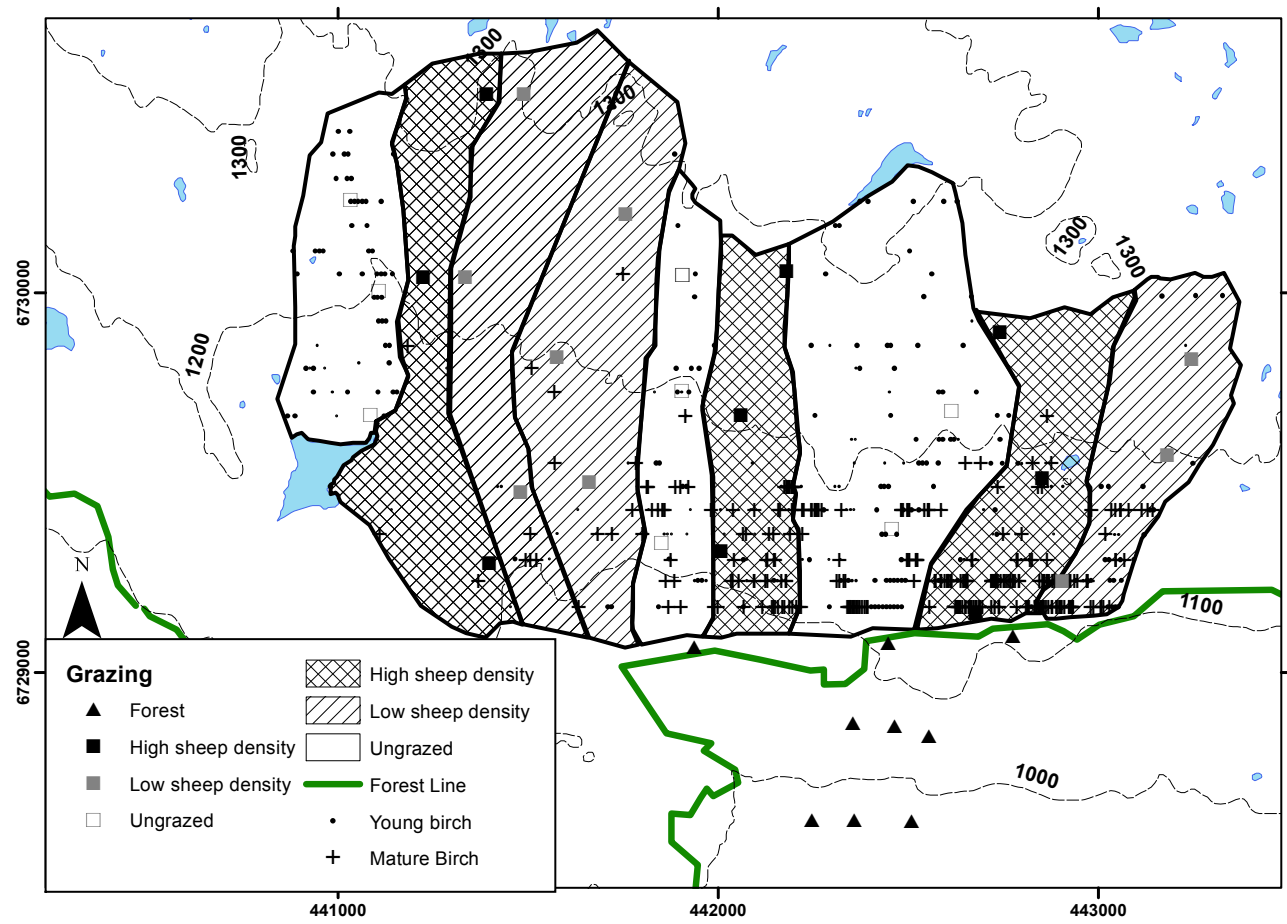

Figure 1. Map of study area and grazing experiment showing the experimental enclosures and locations of sample plots. Observed young and mature birch individuals sampled along transects (Speed et al., 2010) are included for reference, and the thick solid line indicates the forest line. Universal Transverse Mercator grid zone $32 \mathrm{~V}$.

\subsection{Study design}

Three plots were located at each of three elevational levels in forest (Fig. 1), using random stratified sampling during early July 2012 and 2013. In the alpine zone, nine plots were located at each of three elevational levels. One plot was established at each elevational level in each of the nine experimental grazing enclosures; thus there were three plots per elevational level in each of the ungrazed, low-sheep-density and high-sheep-density treatments (Fig. 1). In the ungrazed treatment these were pre-selected at sites where mountain birch has recruited. Plots were selected at equivalent elevation and vegetation in the high and low sheep densities.

\subsection{Birch}

At each alpine plot a $10 \mathrm{~m}$ radius circle was marked, and in each forest plot a $10 \times 10 \mathrm{~m}$ quadrat marked. The difference in area was to allow for the different densities of birch in the two ecosystems. All birch (of any age and size) within the plots were counted, and the basal stem diameter, DBH (diameter at breast height, where applicable) and height were recorded. A random subsample of the birch was destructively harvested to age and determine biomass. Using these subsamples, the relationship between birch basal stem diameter and biomass was estimated using linear regression for individuals with a stem diameter under $50 \mathrm{~mm}$ (Appendix A,
Fig. A1). The biomass of birch with stem diameter over $50 \mathrm{~mm}$ was estimated using the published relationship between biomass and diameter at breast height of mountain birch in mountain areas within the same region (Bollandsås et al., 2009). To estimate the stand age, we used the $75 \%$ quantile of the age (estimated from the relationship between stem diameter and age) of all birch in each plot.

\subsection{Vegetation}

Within each plot, two $50 \times 50 \mathrm{~cm}$ quadrats were randomly located within grassland vegetation in the alpine plots and typical understory vegetation dominated by graminoids and herbs in the forest. The point intercept method was used to determine the relative abundances of species across communities (Jonasson, 1988). All vegetation intercepts were recorded at the species level across 16 pins per quadrat. After point intercept recording, all above-ground vegetation within the quadrat was harvested at ground level. This was dried in ovens at $50^{\circ} \mathrm{C}$ for $48 \mathrm{~h}$ and then dry weight was determined.

\subsection{Soils}

Soil was sampled immediately adjacent to the vegetation quadrats in July 2012 and 2013 using a cylindrical soil auger (diameter $5.2 \mathrm{~cm}$ ). The soil was sampled by genetic horizon and the depth of each horizon was recorded. To obtain enough material for analysis, three to seven soil samples 
from the horizons at each plot were taken and bulked prior to analysis. The organic soil layer $\left(\mathrm{O}_{i}, \mathrm{O}_{\mathrm{ea}}\right.$ or the total organic layer $\mathrm{O}_{i \text { ea }}$ ) was sampled with three replicates from all 36 plots ( 27 inside the enclosures and 9 in the birch forest). Due to difficulties separating the pure $\mathrm{O}$ horizon from the underlying mineral horizon in the birch forest, as caused by arboturbation, the $\mathrm{O}$ horizon represented transition horizons OE or OA. Mixing of organic and mineral material will reduce the soil organic carbon content (SOC) and increase the bulk density of the soil (Martinsen et al., 2011). However, estimates of the ecosystem $\mathrm{C}$ stock will not be affected. Soil from entire profiles (i.e. including $\mathrm{E}, \mathrm{A}$ and, where present, $\mathrm{B}$ and $\mathrm{C}$ horizons, in addition to the organic soil layer) were sampled to a maximum depth of $23.5 \mathrm{~cm}$ (the length of the auger) at 28 of the 36 plots ( 5 out of 9 in the forest and 23 out of 27 in the enclosures, although for two of these sites there was no mineral soil present). Characteristics of organic soil horizons are estimated from three replicates per plot, whereas complete profile estimates are based on between one and three replicates per plot. These replicates were pooled within plots prior to statistical analyses. The upper part of the $\mathrm{C}$ horizon was bulked with the $\mathrm{B}$ horizon. Carbon stocks for the plots with samples from the entire profile thus slightly underestimate the total stocks since the sample was limited to $23.5 \mathrm{~cm}$ depth. C stocks will be further underestimated by the omission of large roots. Soils were stored under cold and dark conditions prior to drying $\left(40^{\circ} \mathrm{C}\right.$ in a drying cabinet; Wascator, type NV-97-1). Bulk density $\left(\mathrm{g} \mathrm{cm}^{-3}\right)$ was determined based on the dry matter mass (after drying at $105^{\circ} \mathrm{C}$ and correcting for amount of roots and gravel $(>2 \mathrm{~mm})$ in the sample) and the sample volume. Subsamples of the dried and sieved samples were further dried at $60^{\circ} \mathrm{C}$ and milled prior to determination of total $\mathrm{C}$ and $\mathrm{N}$ concentration. Total $\mathrm{C}$ and $\mathrm{N}$ were determined by dry combustion (LECO CHN-1000; LECO Corporation, Sollentuna, Sweden) (Nelson and Sommers, 1982) and the Dumas method (Bremmer and Mulvaney, 1982), respectively. Due to the low $\mathrm{pH}$ (mean $\mathrm{pH}_{\mathrm{H}_{2} \mathrm{O}}=4.7$ ), total $\mathrm{C}$ represents organic $\mathrm{C}$, because acid soils do not contain carbonates. For comparisons of SOC $(\%)$, depth-weighted mean values were used for both organic surface $(\mathrm{O})$ horizons and mineral horizons.

\subsection{Quantification of C stocks}

Birch biomass was converted to $\mathrm{C}$ stock by multiplying the value by $52.63 \%$ (C content of mountain birch in the nearby region of Setesdal and at similar elevations; Speed et al., 2014). Vegetation $C$ stock was estimated by multiplying the relative abundance of three growth forms (graminoids, shrubs and herbs) within each quadrat by the mean $\mathrm{C}$ content for that growth form and at the elevation of each plot, estimated from the models presented by Mysterud et al. (2011). Soil C stocks were calculated by multiplying horizon depth, bulk density and $\mathrm{C}$ concentration (Martinsen et al., 2011) and expressed as $\mathrm{kg} \mathrm{C} \mathrm{m}^{-2}$.

\subsection{Statistical analyses}

Non-metric multidimensional scaling (NMDS) of the plant communities was used to explore patterns in plant community composition across the treeline ecotone, using the "vegan" package (Oksanen et al., 2013). We used segmented regression to test whether the slope of the relationship between each the parameters of interest and elevation differed across the treeline ecotone, and to estimate the elevation of the breakpoints, using the statistical package "segmented" (Muggeo, 2008). We thus tested whether the slope differed across a sample size of 36 plots. Sample sizes of around 40 have been found to give acceptable estimates of the locations of breakpoints (Ryan and Porth, 2007). If there was no difference in slope, we used linear models to investigate whether the parameter linearly varied with elevation. We also tested whether the parameters showed linear trends within each of the forest and alpine parts of the elevational gradient, and whether there were significant differences between the parameters above and below the forest line. Finally, we also tested whether there were differences between sheep grazing treatments within the alpine zone. All model residuals were visually inspected. Statistical analyses were undertaken in $\mathrm{R}$ (R Core Team, 2013).

\section{Results}

\subsection{Vegetation}

\subsubsection{Field layer}

Forest field-layer vegetation (defined as all vascular vegetation excluding trees) was dominated by the grasses $D e$ schampsia flexuosa (syn. Avenella flexuosa) and Anthoxanthum odoratum; the fern Gymnocarpium dryopteris; and the herbs Maianthemum, Melampyrum sylvaticum and Geranium sylvaticum (Fig. 2). Alpine field-layer vegetation was dominated by the grasses Nardus stricta and Deschampsia flexuosa as well as the dwarf shrubs Empetrum spp., Vaccinium myrtillus, V. uliginosum and Betula nana across all grazing treatments (Fig. 2). There was a considerable distinction between the field-layer vegetation composition in the forest and the alpine quadrats but a high degree of overlap between the field-layer vegetation composition between the three grazing treatments within the alpine enclosures (Fig. A2).

There was a clear breakpoint in the relationship between the field-layer vegetation $\mathrm{C}$ stock and elevation (Fig. 3a). The breakpoint was estimated to be $1178 \mathrm{~m}$ (95\% confidence interval $1134-1224 \mathrm{~m}, P=0.002)$. There was an increase in the field-layer vegetation $\mathrm{C}$ stock with elevation below this point on the gradient (slope $1.13 \mathrm{~g} \mathrm{C} \mathrm{m}^{-2} \mathrm{~m}^{-1}$ \pm standard error 0.30 ) and a decrease with elevation above this threshold (slope $-1.00 \mathrm{~g} \mathrm{C} \mathrm{m}^{-2} \mathrm{~m}^{-1} \pm 0.49$; Fig. 3a). The mean vegetation field-layer $\mathrm{C}$ stock was higher in the 


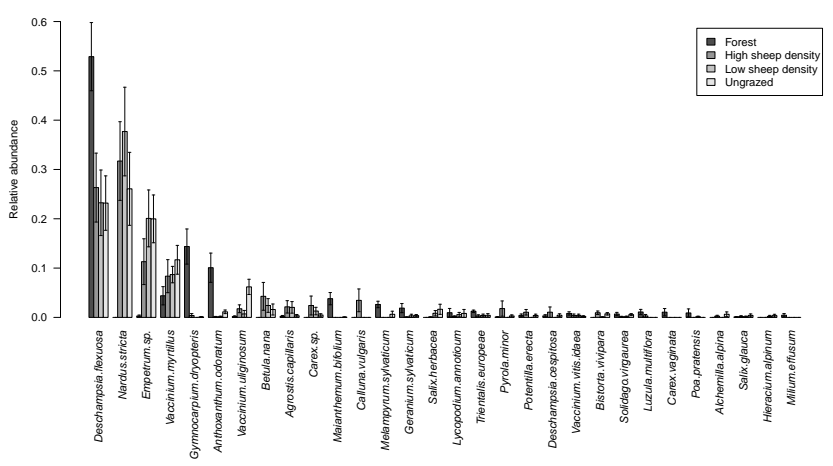

Figure 2. The relative abundance of different field-layer species in the forest zone and different grazing treatments within the alpine zone. The mean number of intercepts per quadrat is shown, along with standard errors. Only species that represent over $0.1 \%$ of the total number of intercepts are shown.

alpine zone $\left(212.2 \mathrm{~g} \mathrm{~m}^{-2} \pm 82.7\right)$ than in the forest zone $\left(82.7 \mathrm{~g} \mathrm{~m}^{-2} \pm 12.4, \quad F_{1,34}=20.75, \quad P<0.001\right)$. The fieldlayer vegetation $\mathrm{C}$ stock did not vary with elevation within either the forest or the alpine zone $\left(F_{1,7}=4.99, P=0.061\right.$ and $F_{1,25}=2.06, P=0.16$ respectively), nor did it vary between the grazing treatments in the alpine zone $\left(F_{2,24}=0.04\right.$, $P=0.96)$.

\subsubsection{Birch}

There was a breakpoint in the relationship between the density of mountain birch individuals and elevation. Below $1120 \mathrm{~m}$ (95\% CI 1067-1172, $P=0.005$ ) the elevational decrease in birch density was steeper (slope $\quad-0.0039$ individuals $\mathrm{m}^{-2} \mathrm{~m}^{-1} \pm 0.0008$ ) than above $1120 \mathrm{~m}$, where it did not differ from 0 (slope -0.0002 individuals $\left.\mathrm{m}^{-2} \mathrm{~m}^{-1} \pm 0.0006\right)$ and birch were present mainly at low densities (Fig. A3).

Birch stand age (as measured by the $75 \%$ quantile of individuals in each plot) decreased linearly along the elevational gradient (Fig. 3b, slope $-0.208 \mathrm{yr} \mathrm{m}^{-1} \pm 0.027$, $\left.F_{1,34}=60.81, P<0.001\right)$ from around 60 years at the lower end of the forest, towards 0 (i.e. birch on average absent) above $1250 \mathrm{~m}$.

There was a breakpoint in the relationship between birch $\mathrm{C}$ stock and elevation $(P<0.001)$. The breakpoint was at $1139 \mathrm{~m}$ (1113-1165). Below this elevation, there was a significant decrease in birch $\mathrm{C}$ stock (slope $\left.-2.14 \mathrm{~g} \mathrm{C} \mathrm{m}^{-2} \mathrm{~m}^{-1} \pm 0.20\right)$, but the slope did not differ from 0 above this elevation $\left(-0.04 \mathrm{~g} \mathrm{C} \mathrm{m}^{-2} \mathrm{~m}^{-1} \pm 0.21\right)$. The birch $\mathrm{C}$ stock was significantly greater in the forest $\left(2702.6 \mathrm{~g} \mathrm{C} \mathrm{m}^{-2} \pm 279.0\right)$ than in the alpine zone $\left(18.2 \mathrm{~g} \mathrm{C} \mathrm{m}^{-2} \pm 9.5, \quad F_{1,34}=291.7, \quad P<0.001\right.$; Fig. $\left.3 b\right)$. Birch $C$ stock decreased with elevation within the forest $\left(F_{1,7}=10.38, P=0.015\right)$ but not within the alpine zone $\left(F_{1,25}=1.33, P=0.72\right.$; Fig. $\left.3 \mathrm{c}\right)$. Birch $\mathrm{C}$ stock did not differ between the grazing treatments in the alpine zone $\left(F_{2,24}=1.87, P=0.18\right.$; Fig. $\left.3 c\right)$.

\subsubsection{Total vegetation}

There was a breakpoint in the relationship between total vegetation $C$ stock and elevation within the treeline ecotone. The breakpoint was at $1136 \mathrm{~m}(1109-1164, P<0.001$; Fig. 3d). Total vegetation $\mathrm{C}$ stock decreased with elevation below this point (slope $-22.2 \mathrm{~g} \mathrm{C} \mathrm{m}^{-2} \mathrm{~m}^{-1} \pm 2.1$ ) but did not change with elevation above this point $\left(-1.064 \mathrm{~g} \mathrm{C} \mathrm{m}^{-2} \mathrm{~m}^{-1} \pm 2.229\right)$. Total vegetation $\mathrm{C}$ stock was significantly greater in the forest $\left(2785.3 \mathrm{~g} \mathrm{C} \mathrm{m}^{-2} \pm 271.0\right)$ than in the alpine zone $\left(230.4 \mathrm{~g} \mathrm{~m}^{-2} \pm 21.0, F_{1,34}=267.5\right.$, $P<0.001$; Fig. 3d). Total vegetation biomass decreased with elevation within the forest zone $\left(F_{1,7}=10.38, P=0.015\right.$; Fig. 3d) but did not vary with elevation $\left(F_{1,24}=1.53\right.$, $P=0.23)$, nor between grazing treatments in the alpine zone $\left(F_{2,24}=0.50, P=0.79\right.$; Fig. $\left.3 \mathrm{~d}\right)$

\subsection{Soil}

\subsubsection{Soil organic carbon concentration}

Soil organic carbon concentration (SOC \%) increased linearly within organic soil horizons (based on all 36 plots) with elevation across the ecotone $\left(F_{1,34}=42.09, P<0.001\right.$; Fig. 4a), and the slope did not vary with elevation $(P=0.55)$. SOC was significantly greater in alpine organic horizons $(27.6 \% \pm 1.2)$ than in forest organic horizons $(13.3 \% \pm 0.9$, $F_{1,34}=46.01, \quad P<0.001$; Fig. 4a). SOC of the organic horizon increased with elevation within the alpine zone $\left(F_{1,25}=6.87, P=0.015\right)$ but not within the forest zone $\left(F_{1,7}=0.52, P=0.49\right.$; Fig. 4a). It also did not differ between grazing treatments in the alpine zone $\left(F_{2,24}=1.03\right.$, $P=0.37$; Fig. 4a). Organic soil horizon depth did not vary with elevation but was on average $1 \mathrm{~cm}$ deeper in the alpine zone $(3.6 \mathrm{~cm} \pm 0.26)$ than in the forest zone $\left(2.6 \mathrm{~cm} \pm 0^{\circ} .42\right.$, $F_{1,34}=4.24, P=0.047$ ) (Fig. A4a).

Depth weighted \% SOC of the mineral horizons (based on the 26 plots with a mineral sub-soil) did not vary with elevation, although this was marginal $\left(F_{1,24}=4.24, P=0.051\right.$; Fig. 4b), and there was no change in the slope across the elevational gradient $(P=0.86)$. Mineral SOC was, however, significantly greater in the alpine zone $(3.56 \% \pm 0.28)$ than in the forest zone $\left(2.22 \% \pm 0.26, F_{1,24}=5.01, P=0.03\right.$; Fig. 4b). Mineral soil SOC did not vary with elevation within the forest zone $\left(F_{1,3}=2.66, P=0.20\right)$, nor within the alpine zone $\left(F_{1,19}=0.43, P=0.52\right.$; Fig. $\left.4 \mathrm{~b}\right)$, and did not vary between the grazing treatments within the alpine zone $\left(F_{2,18}=2.99, P=0.08\right.$; Fig. $\left.4 b\right)$. Mineral soil horizon depth did not vary with elevation, nor did it vary between the alpine and forest zones (Fig. A4b). 

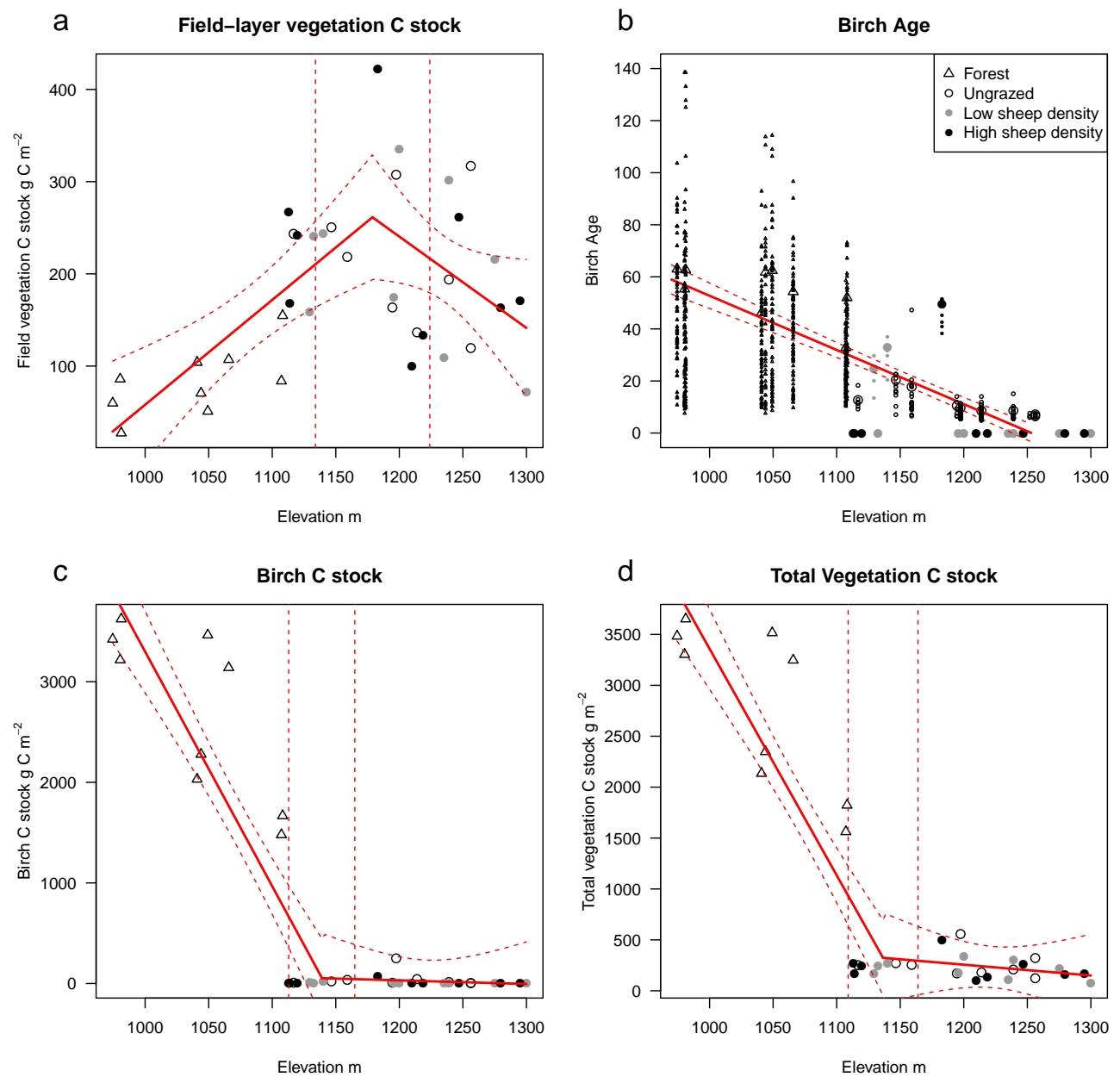

Figure 3. (a) The $\mathrm{C}$ stock of the field-layer vegetation (b), the age of birch in each plot, (c) the $\mathrm{C}$ stock in the above-ground birch stands, and (d) the total above-ground vegetation $\mathrm{C}$ stock all plotted along the elevational gradient. Each plot is represented by a point, averaged across two quadrats for the field-layer vegetation. Means and standard errors are shown by regression lines. The vertical dashed lines show the $95 \%$ confidence intervals of the break points in the segmented regression, where there was a significant difference in slope across the elevational gradient $(P<0.05)$. In (b) the estimated age of each sampled tree is plotted, while the regression line is based on the $75 \%$ quantile value. The $75 \%$ quantile individual is shown with a larger point within each plot.

\subsubsection{C stocks}

Carbon stocks of the organic horizons (based on all 36 plots) increased with elevation $\left(F_{1,34}=8.46, P=0.006\right.$; Fig. 4 c) and there was no difference in the slope along the elevational gradient $(P=0.21)$. Organic horizon $\mathrm{C}$ stock was significantly lower in forest $\left(1.01 \mathrm{~kg} \mathrm{C} \mathrm{m}^{-2} \pm 0.18\right)$ than in alpine soils (2.13 $\mathrm{kg} \mathrm{C} \mathrm{m}^{-2} \pm 0.21, F_{1,34}=8.33, P=0.007$; Fig. 4c). Organic soil $\mathrm{C}$ stock did not vary with elevation within either the forest $\left(F_{2,7}=0.05, P=0.82\right)$ or the alpine part of the gradient $\left(F_{2,25}=0.97, P=0.33\right)$, nor did it differ between grazing treatments in the alpine zone $\left(F_{2,24}=0.84\right.$, $P=0.44$; Fig. 4c).

Mineral soil C stock (based on the 26 plots with a mineral sub-soil) did not increase with elevation $\left(F_{1,26}=1.17, \quad P=0.29 ; \quad\right.$ Fig. $\left.4 d\right)$ and there was no change in the slope along the elevational gradient $(P=0.43)$. Mineral soil $\mathrm{C}$ stock did not significantly differ between forest $\left(1.80 \mathrm{~kg} \mathrm{C} \mathrm{m}^{-2} \pm 0.32\right)$ and alpine soils $\left(2.25 \mathrm{~kg} \mathrm{C} \mathrm{m}^{-2} \pm 0.23, \quad F_{1,26}=0.76, \quad P=0.38\right.$; Fig. $\left.4 \mathrm{~d}\right)$. Mineral soil $\mathrm{C}$ stock did not vary with elevation within either the forest $\left(F_{2,3}=2.82, P=0.19\right)$ or the alpine $\left(F_{2,21}=0.77\right.$, $P=0.39)$ parts of the elevational gradient, nor did it differ between grazing treatments in the alpine zone $\left(F_{2,8}=0.04\right.$, $P=0.95$; Fig. $4 \mathrm{~d})$.

\subsection{Ecosystem carbon stocks}

The total ecosystem carbon stock (based on a total of 28 plots; 26 with a full mineral profile sampled plus 2 where the whole profile comprised organic horizons only) showed a discontinuous response to elevation across the treeline ecotone. The breakpoint was at $1139 \mathrm{~m}(1066-1212, P=0.04$; 

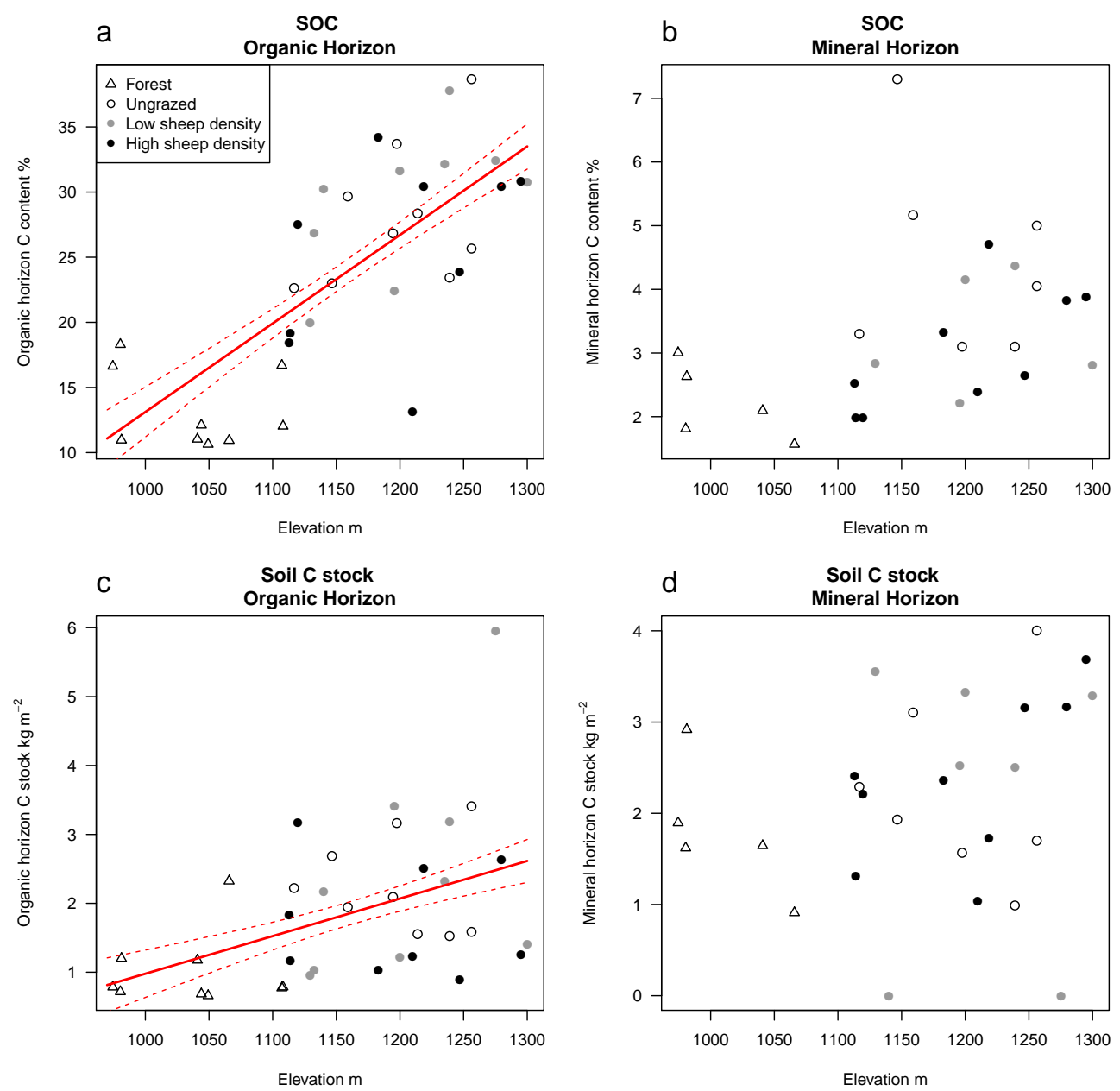

Figure 4. C content (\%) of (a) organic soil horizons and (b) mineral soil horizons weighted by the depth of sub-horizons along the elevational gradient and $\mathrm{C}$ stocks $\left(\mathrm{kg} \mathrm{m}^{-2}\right)$ of the (c) organic and (d) mineral soil horizons across the elevational gradient. Means and standard errors are shown by regression lines where significant. Each point represents a plot, averaged across multiple samples. Only plots for which a full soil profile was sampled are included in the mineral soil figures. The depths of the organic and mineral soil horizons are shown in Appendix A, Fig. A4.

Fig. 5). Below this elevation there was a decrease in ecosystem $\mathrm{C}$ stock with elevation $\left(-0.015 \mathrm{~kg} \mathrm{C} \mathrm{m}^{-2} \mathrm{~m}^{-1} \pm 0.007\right)$, but above this elevation there was an increase in ecosystem C stock (0.008 $\left.\mathrm{kg} \mathrm{C} \mathrm{m}^{-2} \mathrm{~m}^{-1} \pm 0.006\right)$. Ecosystem $\mathrm{C}$ stock was on average greater in the forest $\left(6.20 \mathrm{~kg} \mathrm{C} \mathrm{m}^{-2} \pm 0.47\right)$ than in the alpine zone $\left(4.69 \mathrm{~kg} \mathrm{C} \mathrm{m}^{-2} \pm 0.25, F_{1,26}=6.98\right.$, $P=0.014)$. The ecosystem $C$ stock did not vary with elevation within either the forest $\left(F_{1,3}=0.26, P=0.64\right)$ or the alpine part of the gradient $\left(F_{1,21}=2.30, P=0.15\right)$, nor did it vary with grazing treatment within the alpine zone $\left(F_{2,20}=0.79, P=0.67\right)$.

\section{Discussion}

The treeline is a prominent ecotone separating the widely different ecosystems of boreal forest and alpine or Arctic tundra. As many treelines are currently advancing in alpine re- gions around the world (Harsch et al., 2009), understanding the implications for $\mathrm{C}$ storage is critically important from a climate change perspective (Sjögersten and Wookey, 2009). In this study we demonstrate that there is a discontinuum in the relationship between ecosystem carbon stock and elevation which falls between the forest line and treeline. Below the treeline, ecosystem carbon stock decreases with elevation $\left(-15 \mathrm{~g} \mathrm{~m}^{-2}\right.$ per metre increase in elevation), while above the treeline ecosystem $\mathrm{C}$ stock increases with elevation $\left(8 \mathrm{~g} \mathrm{~m}^{-2}\right.$ per metre increase in elevation). This discontinuum is driven by threshold changes in above-ground field-layer vegetation and birch $\mathrm{C}$ stocks, as well as higher organic soil $\mathrm{C}$ stocks in alpine tundra than forests. This finding suggests that, for at least some treelines, the threshold in vegetation $\mathrm{C}$ stocks within the treeline ecotone can outweigh the higher organic horizon soil $\mathrm{C}$ stocks in alpine vegetation, such that ecosystem $\mathrm{C}$ storage is at a trough between the forest line and tree- 


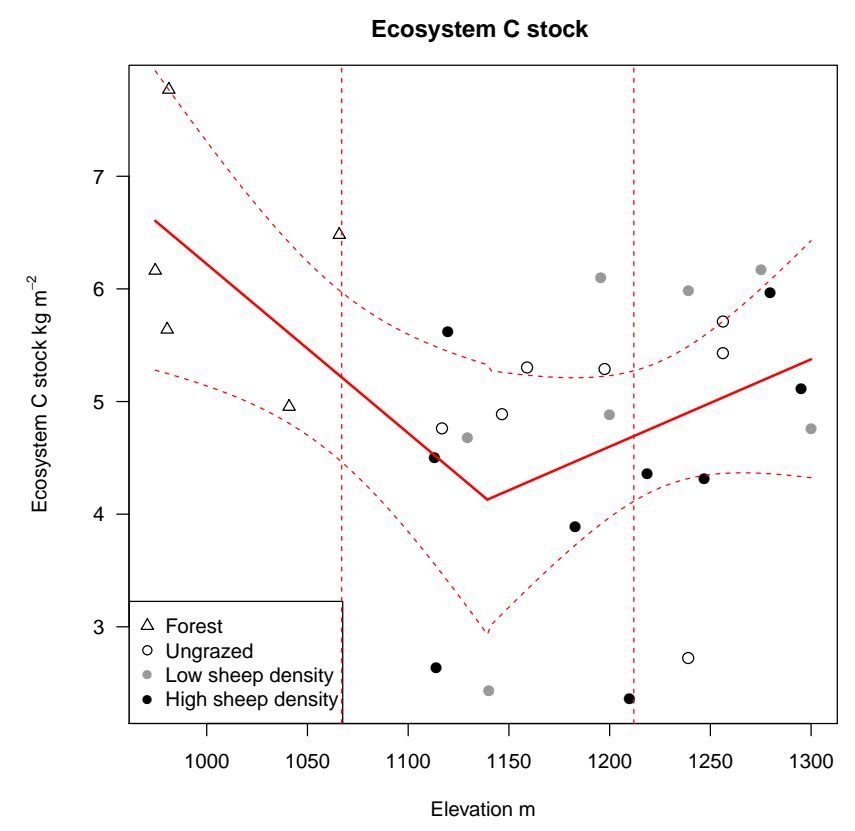

Figure 5. Ecosystem carbon, including field-layer vegetation, birch, and organic and mineral soil horizons. Means and standard errors are shown by regression lines. Each point represents a plot. Only plots for which a full soil profile was sampled are included. The vertical dashed lines show the $95 \%$ confidence intervals of the break points in the segmented regression, where there was a significant difference in slope across the elevational gradient $(P<0.05)$.

line. The implication of this is that ecosystem $\mathrm{C}$ stocks will not respond linearly to forest expansion into tundra, and as we demonstrate by contrasting the mean alpine and mean forest $\mathrm{C}$ stocks, comparative studies of tundra and forest ecosystems miss some of the complexities of the overall elevational gradient.

Tundra and forest ecosystems appear to be alternate stable states; intermediate tree covers are less common (Scheffer et al., 2012). These two stable states have different predominant $\mathrm{C}$ stocks: in soil organic matter in the alpine system and in woody biomass in the forest system. We find a transition between forest and alpine tundra ecosystem $\mathrm{C}$ stocks. Forest soils have greater turnover rates in the topsoils than non-forest soils (see Mills et al., 2014), resulting in lower accumulation of $\mathrm{C}$ in the $\mathrm{O}$ horizon, but this is compensated for by an increase in vegetation $\mathrm{C}$ storage with increasing biomass of trees. Thus, the breakpoint in ecosystem $\mathrm{C}$ storage (falling between the forest line and treeline) represents a trough and an intermediate state of $\mathrm{C}$ storage. Here soil $\mathrm{C}$ storage is reduced by higher plant activity (driven by an upslope shift in lowland plant species; Speed et al., 2012), but above-ground vegetation $\mathrm{C}$ stocks have not yet increased, as tree establishment is a slow process and is limited at this site by herbivory as well as climate.

Although we found a linear increase in $\mathrm{C}$ stocks within the organic horizon across the treeline ecotone, we did not see any trend with elevation within either the forest or alpine zones; thus the linear increase across the whole gradient may be an artefact of the differences between forest and alpine ecosystems. This highlights the importance of considering vegetation state in addition to elevation when addressing $\mathrm{C}$ stocks across ecotones. Mineral horizon $\mathrm{C}$ stock was unrelated to elevation. In contrast, vegetation $\mathrm{C}$ stock showed a clearly discontinuous decrease at the forest line. Treeline advance may therefore increase above-ground $\mathrm{C}$ stocks but have a lower-magnitude negative impact on below-ground $\mathrm{C}$ stocks. This negative impact is likely to be due to the stimulation of decomposition of older organic material by higher plant activity in tree-dominated ecosystems as demonstrated at both Fennoscandian (Hartley et al., 2012) and Alaskan treelines (Wilmking et al., 2006), as well as higher degradability of $\mathrm{C}$ in forest soils than tundra soils (Kammer et al., 2009). One of the processes linked to treeline advance is the decomposition of old organic soil carbon associated with the colonisation of trees (Sjögersten and Wookey, 2009; Hartley et al., 2012). Therefore, a factor that is likely to modulate the ecosystem carbon stock across the treeline ecotone is the age of the tree stand. In our study the stand age decreased linearly with elevation, as would be expected at an advancing treeline (see Hallinger et al., 2010). Thus, in our study, elevation is partially confounded with birch stand age, and a ${ }^{14} \mathrm{C}$ approach examining the age of respired $\mathrm{C}$, as implemented by Hartley et al. (2012), would be required to investigate the linkage between birch stand age and the age of the respired carbon.

Grazing was predicted to affect both above- and belowground $\mathrm{C}$ stocks, and the impact expected to vary with herbivore density. In another southern Scandes site (Setesdal Vesthei), open tundra had a lower above-ground $\mathrm{C}$ store than the forest, and equal $\mathrm{C}$ stocks at similar elevations, and the difference in ecosystem state was attributable to the long-term influence of grazing livestock (over several decades; Speed et al., 2014). In the current study, we found no difference in any $\mathrm{C}$ stocks between the different grazing treatments. This is despite the fact that birch establishment and growth is limited by livestock herbivory at this site (Speed et al., 2010, 2011a, b) and grassland soil $\mathrm{C}$ storage in organic horizons peaks at low sheep densities (Martinsen et al., 2011). However, development of carbon stocks is a slow process at such high elevations, and after 12 years of experimental grazing the establishing birch are not yet at a size where they substantially contribute to $\mathrm{C}$ stocks.

Under a warming climate, the treeline can be expected to rise (Körner and Paulsen, 2004). Predictions for future climatic warming at our study site are between 2.5 and $3.5^{\circ} \mathrm{C}$ (depending on the scenario and model) by 2100 (EngenSkaugen et al., 2008). Soil temperature (growing season, $5 \mathrm{~cm}$ depth) at the study site decreases by $1.4^{\circ} \mathrm{C}$ per $100 \mathrm{~m}$ elevation within the alpine zone (V. Martinsen, unpublished data). If the ecosystem tracked climatic change, we could then expect the trough of ecosystem C storage to shift around 
$200 \mathrm{~m}$ upslope. High-alpine ecosystems would thus have a decrease in ecosystem $\mathrm{C}$ storage, and low-alpine ecosystems would see an increase in ecosystem $\mathrm{C}$ storage. However, in practice, local-scale factors are likely to limit the rate of treeline rise (Danby, 2011), of which herbivory is likely to be crucial within the current study region (Speed et al., 2010).

Using the observed pattern in $\mathrm{C}$ stocks across this dynamic treeline ecotone, we propose a progression of ecosystem C stock responses to treeline advance in a warmer climate. (1) In the short term (around 5 years), temperature-limited soil processes such as decomposition may increase, reducing soil C stocks, while increased growth of vegetation (Arft et al., 1999) may increase above-ground $C$ stocks and hence litter inputs. At this stage the impact on ecosystem $\mathrm{C}$ stocks will be minor. (2) On a longer timescale (decades) shifts in vegetation composition (Speed et al., 2013) may occur, and increased tree recruitment and growth above the treeline may become apparent (Speed et al., 2011b). Any vegetation changes are likely to lead to changes in litter quality, increasing the decomposability of soil organic matter (Kammer et al., 2009). At this stage, the ecosystem $C$ storage is likely to reach a minimum. (3) In the longer term (several decades to centuries), forest development will lead to development of above-ground stocks partially compensating for decreases in soil C stocks (Speed et al., 2014).
Although ecosystem carbon stocks may respond to a climatically driven treeline advance, this pattern may be buffered by herbivory. Previous studies have demonstrated how herbivores can prevent climate-driven advancement of trees and shrubs into tundra (Speed et al., 2010; Olofsson et al., 2009), increases in biomass (Kaarlejärvi et al., 2013; Post and Pedersen, 2008) and upslope movement of plant communities (Speed et al., 2012). Thus future ecosystem C stocks at and above the treeline will depend upon both future climatic conditions and herbivore densities.

A number of drivers including climate and land-use changes are driving shifts in treelines globally, and these are expected to have substantial influences feeding back to the global climate due to the impact of the tundra to forest transition on carbon balance and albedo. We have demonstrated that this ecotone transition is associated with a threshold change in vegetation $\mathrm{C}$ stock along an elevational gradient, as well as higher organic horizon $\mathrm{C}$ stocks in the alpine zone than the forest zone. Furthermore, there is some evidence that the total ecosystem carbon stock reaches a trough between the forest line and treeline, increasing both at lower forest elevations and at higher alpine elevations. Thus estimates and models of carbon storage in relation to treeline shifts need to account for threshold relationships associated with ecosystem state transitions across the treeline ecotone. 


\section{Appendix A}

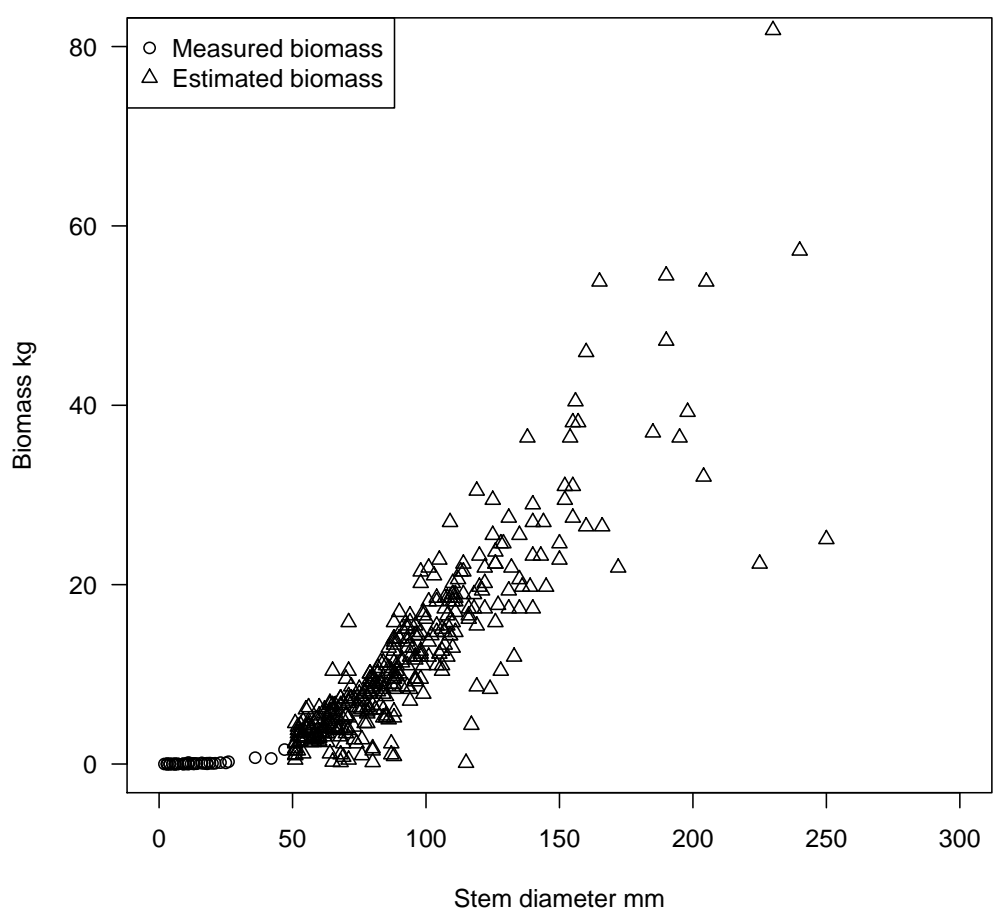

Figure A1. Biomass of birch stems directly measured (stem diameter $<50 \mathrm{~mm}$ ) or estimated from published relationships (stem diameter $>50 \mathrm{~mm}$ ) for mountain birch in alpine areas of southern Norway (Bollandsås et al., 2009).

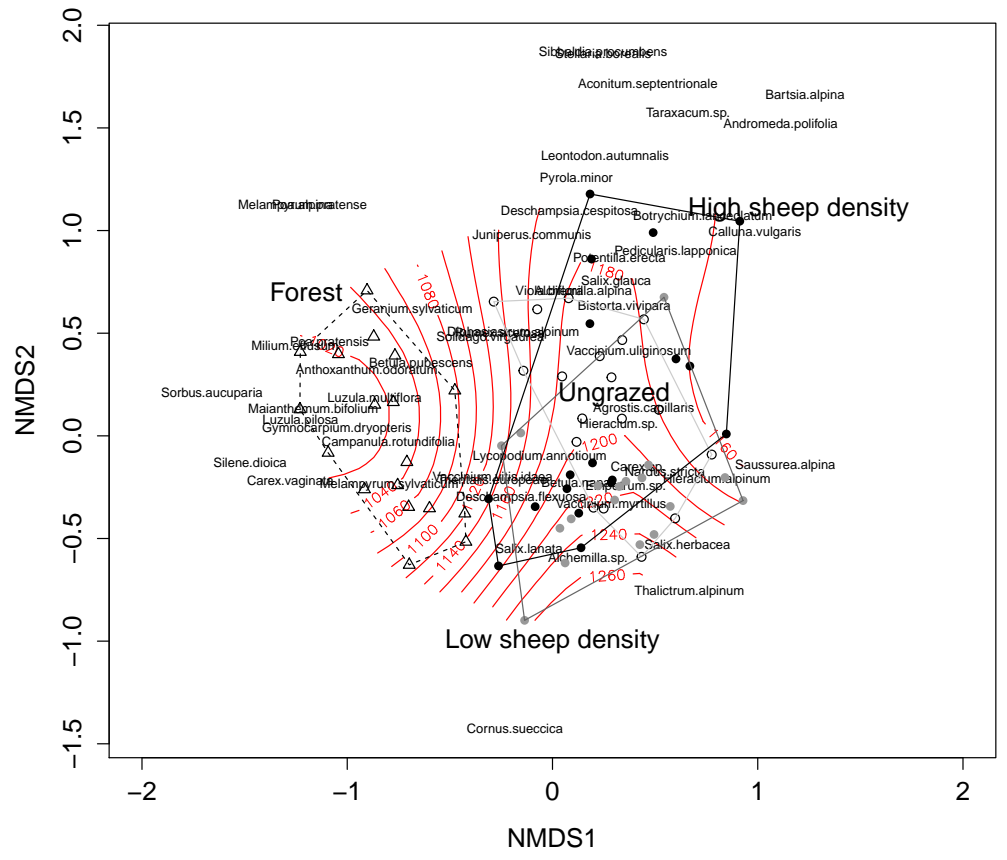

Figure A2. Non-metric multidimensional scaling (NMDS) ordination of the field-layer vegetation across the elevational gradient. Each point represents a quadrat ( 2 per plot) plotted along the first and second axes. The red contour lines show thin plane splines fit for elevation across the quadrats. Convex hulls are drawn around the quadrats from the forest region and each grazing treatment and labelled appropriately. Species scores are also shown and labelled by species name. 


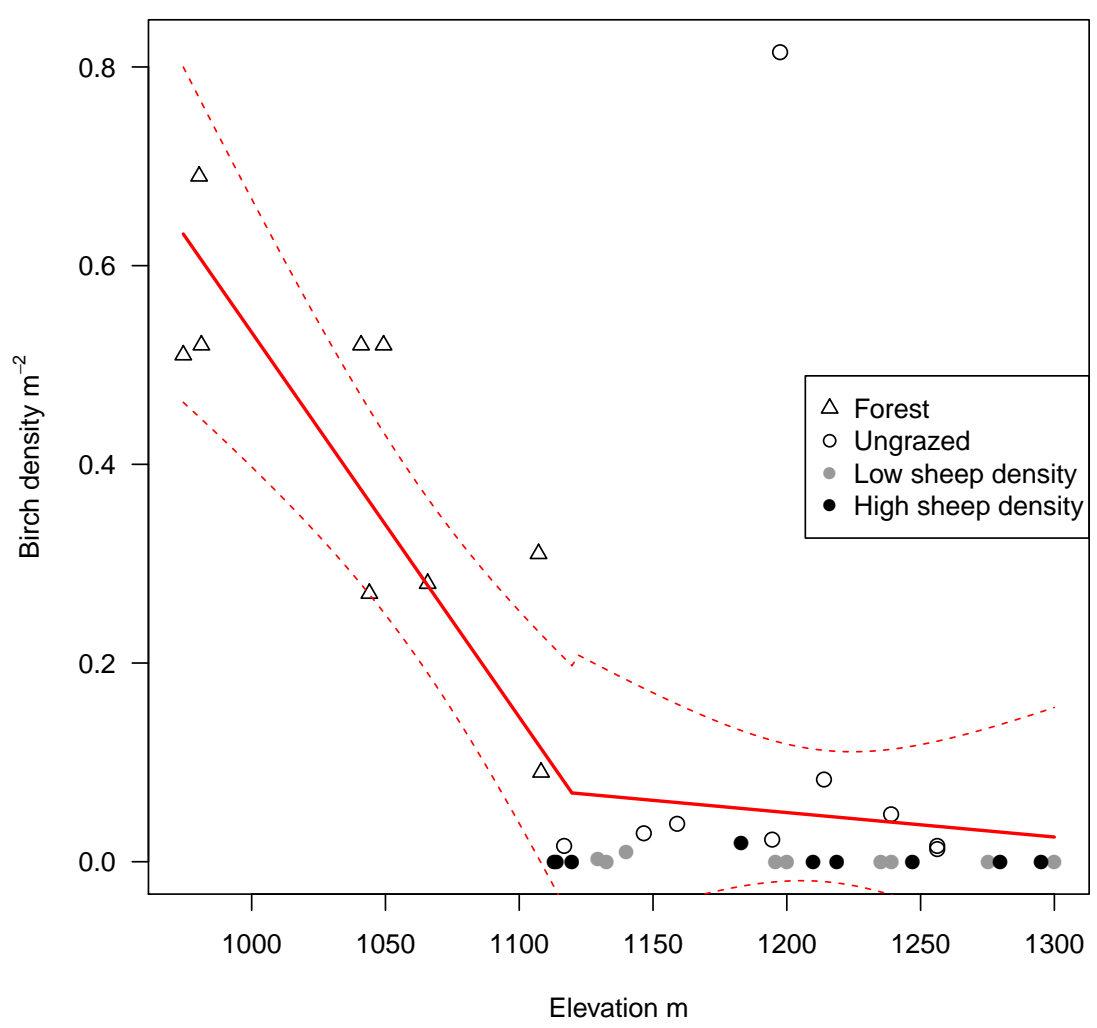

Figure A3. The density of birch individuals across the forest and alpine plots. Means and standard errors are shown by regression lines. The vertical dashed lines show the $95 \%$ confidence intervals of the break points in the segmented regression.
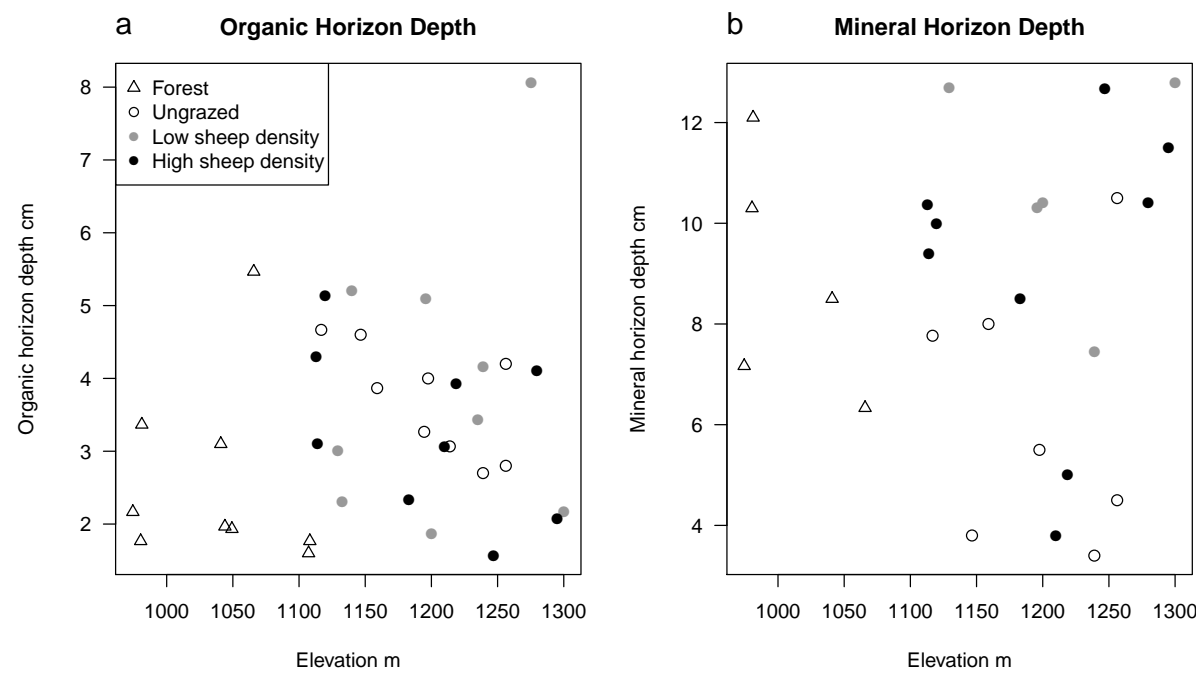

Figure A4. The depth of (a) organic and (b) mineral soil horizons along the elevational gradient. Each point represents a plot, averaged across 3 samples for the organic horizon and 1-3 samples for the mineral horizon. Only plots for which a full soil profile was sampled are included in the mineral soil figures. Neither variable showed a significant relationship with elevation. 
Author contributions. G. Austrheim, V. Martinsen and J. D. M. Speed performed fieldwork. J. D. M. Speed processed and analysed vegetation samples and data, and V. Martinsen processed and analysed soil samples and data. G. Austrheim and A. Mysterud initiated the grazing experiment. All authors contributed to the design and implementation of the study. J. D. M. Speed wrote the manuscript with contribution from all co-authors.

Acknowledgements. We are grateful to the Research Council of Norway for funding through the Environment 2015 programme (ManEco project 212897). We also thank Maxime Brousseau, Clémence Koren, Silke Kunz, Marie Maurset and Magdalena Rygalska for assistance in the field and the laboratory. Finally, we express our gratitude to the three anonymous referees for their constructive comments and input.

Edited by: J.-A. Subke

\section{References}

Arft, A. M., Walker, M. D., Gurevitch, J., Alatalo, J. M., Bret-Harte, M. S., Dale, M., Diemer, M., Gugerli, F., Henry, G. H. R., Jones, M. H., Hollister, R. D., Jonsdottir, I. S., Laine, K., Levesque, E., Marion, G. M., Molau, U., Molgaard, P., Nordenhall, U., Raszhivin, V., Robinson, C. H., Starr, G., Stenstrom, A., Stenstrom, M., Totland, O., Turner, P. L., Walker, L. J., Webber, P. J., Welker, J. M., and Wookey, P. A.: Responses of tundra plants to experimental warming: Meta-analysis of the international tundra experiment, Ecol. Monogr., 69, 491-511, 1999.

Bardgett, R. D. and Wardle, D. A.: Aboveground-Belowground Linkages: Biotic Interactions, Ecosystem Processes and Global Change, OUP Oxford, 2010.

Bollandsås, O. M., Rekstad, I., Næsset, E., and Røsberg, I.: Models for predicting above-ground biomass of Betula pubescens spp. czerepanovii in mountain areas of southern Norway, Scand. J. Forest Res., 24, 318-332, doi:10.1080/02827580903117412, 2009.

Bremmer, J. M. and Mulvaney, C. S.: Nitrogen-total, in: Methods of soil analysis Part 2 Agronomy 9, edited by: Page, A. L., Miller, R. H., and Keeney, D. R., American Society of Agronomy, Madison, Wisconsin, USA, 595-624, 1982.

Cairns, D. M. and Moen, J.: Herbivory influences tree lines, J. Ecol., 92, 1019-1024, 2004.

Chapin, F. S., McGuire, A. D., Randerson, J., Pielke, R., Baldocchi, D., Hobbie, S. E., Roulet, N., Eugster, W., Kasischke, E., Rastetter, E. B., Zimov, S. A., and Running, S. W.: Arctic and boreal ecosystems of western North America as components of the climate system, Glob. Change Biol., 6, 211-223, doi:10.1046/j.1365-2486.2000.06022.x, 2000.

Danby, R. K.: Monitoring Forest-Tundra Ecotones at Multiple Scales, Geography Compass, 5, 623-640, doi:10.1111/j.17498198.2011.00447.x, 2011.

de Wit, H. A., Bryn, A., Hofgaard, A., Karstensen, J., Kvalevåg, M. M., and Peters, G. P.: Climate warming feedback from mountain birch forest expansion: reduced albedo dominates carbon uptake, Glob. Change Biol., 20, 2344-2355, doi:10.1111/gcb.12483, 2014.
Engen-Skaugen, T., Haugen, J., and Hanssen-Bauer, I.: Dynamically downscaled climate scenarios available at the Norwegian Meteorological Institute, 2008.

Eugster, W., Rouse, W. R., Pielke Sr., R. A., McFadden, J. P., Baldocchi, D. D., Kittel, T. G. F., Chapin, F. S., Liston, G. E., Vidale, P. L., Vaganov, E., and Chambers, S.: Land-atmosphere energy exchange in Arctic tundra and boreal forest: available data and feedbacks to climate, Glob. Change Biol., 6, 84-115, doi:10.1046/j.1365-2486.2000.06015.x, 2000.

Gehrig-Fasel, J., Guisan, A., and Zimmermann, N. E.: Tree line shifts in the Swiss Alps: Climate change or land abandonment?, J. Veg. Sci., 18, 571-582, doi:10.1658/11009233(2007)18[571:tlsits]2.0.co;2, 2007.

Hallinger, M., Manthey, M., and Wilmking, M.: Establishing a missing link: warm summers and winter snow cover promote shrub expansion into alpine tundra in Scandinavia, New Phytol., 186, 890-899, doi:10.1111/j.1469-8137.2010.03223.x, 2010.

Harsch, M. A., Hulme, P. E., McGlone, M. S., and Duncan, R. P.: Are treelines advancing? A global meta-analysis of treeline response to climate warming, Ecol. Lett., 12, 1040-1049, doi:10.1111/j.1461-0248.2009.01355.x, 2009.

Hartley, I. P., Garnett, M. H., Sommerkorn, M., Hopkins, D. W., Fletcher, B. J., Sloan, V. L., Phoenix, G. K., and Wookey, P. A.: A potential loss of carbon associated with greater plant growth in the European Arctic, Nature Clim. Change, 2, 875-879, 2012.

Jonasson, S.: Evaluation of the point intercept method for the estimation of plant biomass, Oikos, 52, 101-106, 1988.

Kaarlejärvi, E., Eskelinen, A., and Olofsson, J.: Herbivory prevents positive responses of lowland plants to warmer and more fertile conditions at high altitudes, Funct. Ecol., 27, 1244-1253, doi:10.1111/1365-2435.12113, 2013.

Kammer, A., Hagedorn, F., Shevchenko, I., Leifeld, J., Guggenberger, G., Goryacheva, T., Rigling, A., and Moiseev, P.: Treeline shifts in the Ural mountains affect soil organic matter dynamics, Glob. Change Biol., 15, 1570-1583, doi:10.1111/j.13652486.2009.01856.x, 2009.

Körner, C. and Paulsen, J.: A world-wide study of high altitude treeline temperatures, J. Biogeogr., 31, 713-732, 2004.

Martinsen, V., Mulder, J., Austrheim, G., and Mysterud, A.: Carbon storage in low-alpine grassland soils: effects of different grazing intensities of sheep, Eur. J. Soil Sci., 62, 822-833, doi:10.1111/j.1365-2389.2011.01393.x, 2011.

Mills, R. T. E., Tipping, E., Bryant, C. L., and Emmett, B. A.: Longterm organic carbon turnover rates in natural and semi-natural topsoils, Biogeochemistry, 118, 257-272, doi:10.1007/s10533013-9928-z, 2014.

Muggeo, V. M. R.: segmented: an R Package to Fit Regression Models with Broken-Line Relationships, R News, 8/1, 20-25 http://cran.r-project.org/doc/Rnews/, 2008.

Myers-Smith, I. H., Forbes, B. C., Wilmking, M., Hallinger, M., Lantz, T., Blok, D., Tape, K. D., Macias-Fauria, M., SassKlaassen, U., Lévesque, E., Boudreau, S., Ropars, P., Hermanutz, L., Trant, A., Collier, L. S., Weijers, S., Rozema, J., Rayback, S. A., Schmidt, N. M., Schaepman-Strub, G., Wipf, S., Rixen, C., Ménard, C. B., Venn, S., Goetz, S., Andreu-Hayles, L., Elmendorf, S., Ravolainen, V., Welker, J., Grogan, P., Epstein, H. E., and Hik, D. S.: Shrub expansion in tundra ecosystems: dynamics, impacts and research priorities, Environ. Res. Lett., 6, 045509, doi:10.1088/1748-9326/6/4/045509, 2011. 
Mysterud, A., Hessen, D. O., Mobæk, R., Martinsen, V., Mulder, J., and Austrheim, G.: Plant quality, seasonality and sheep grazing in an alpine ecosystem, Basic Appl. Ecol., 12, 195-206, 2011.

Nelson, D. W. and Sommers, L. E.: Total Carbon, Organic Carbon and Organic Matter, in: Methods of soil analysis Part 2 Agronomy 9, edited by: Page, A. L., Miller, R. H., and Keeney, D. R., American Society of Agronomy, Madison, Wisconsin, USA, 539-579, 1982.

Oksanen, J., Blanchet, F. G., Kindt, R., Legendre, P., Minchin, P. R., O’Hara, R. B., Simpson, G. L., Solymos, P., Stevens, M. H. H., and Wagner, H.: vegan: Community Ecology Package R package version 1.17-3, available at: http://CRAN.R-project.org/ package=vegan, 2013 .

Olofsson, J., Oksanen, L., Callaghan, T., Hulme, P. E., Oksanen, T., and Suominen, O.: Herbivores inhibit climate-driven shrub expansion on the tundra, Glob. Change Biol., 15, 2681-2693, doi:10.1111/j.1365-2486.2009.01935.x, 2009.

Post, E. and Pedersen, C.: Opposing plant community responses to warming with and without herbivores, P. Natl. Acad. Sci. USA., 105, 12353-12358, 2008.

Ryan, S. E. and Porth, L. S.: A tutorial on the piecewise regression approach applied to bedload transport data, US Department of Agriculture, Forest Service, Rocky Mountain Research Station, 46 pp., 2007.

Scheffer, M., Hirota, M., Holmgren, M., Van Nes, E. H., and Chapin, F. S.: Thresholds for boreal biome transitions, P. Natl. Acad. Sci. USA, 109, 21384-21389, doi:10.1073/pnas.1219844110, 2012.

Sjögersten, S. and Wookey, P. A.: The impact of climate change on ecosystem carbon dynamics at the Scandinavian mountain birch forest-tundra heath ecotone, AMBIO, 38, 2-10, 2009.

Sjögersten, S., Alewell, C., Cécillon, L., Hagedorn, F., Jandl, R., Leifeld, J., Martinsen, V., Schindlbacher, A., Sebastià, M., and Van Miegroet, H.: Mountain soils in a changing climate - vulnerability of carbon stocks and ecosystem feedbacks, in: Soil Carbon in Sensitive European Ecosystems: From Science to Land Management, edited by: Jandl, R., Rodeghiero, M., and Olsson, M., Wiley-Blackwell, Chichester, 118-148, 2011.
Speed, J. D. M., Austrheim, G., Hester, A. J., and Mysterud, A.: Experimental evidence for herbivore limitation of the treeline, Ecology, 91, 3414-3420, doi:10.1890/09-2300, 2010.

Speed, J. D. M., Austrheim, G., Hester, A. J., and Mysterud, A.: Growth limitation of mountain birch caused by sheep browsing at the altitudinal treeline, Forest Ecol. Manag., 261, 1344-1352, doi:10.1016/j.foreco.2011.01.017, 2011a.

Speed, J. D. M., Austrheim, G., Hester, A. J., and Mysterud, A.: Browsing interacts with climate to determine tree-ring increment, Funct. Ecol., 25, 1018-1023, doi:10.1111/j.13652435.2011.01877.x, 2011b.

Speed, J. D. M., Austrheim, G., Hester, A. J., and Mysterud, A.: Elevational advance of alpine plant communities is buffered by herbivory, J. Veg. Sci., 23, 617-625, doi:10.1111/j.16541103.2012.01391.x, 2012.

Speed, J. D. M., Austrheim, G., and Mysterud, A.: The response of plant diversity to grazing varies along an elevational gradient, J. Ecol., 101, 1225-1236, doi:10.1111/1365-2745.12133, 2013.

Speed, J. D. M., Martinsen, V., Mysterud, A., Mulder, J., Holand, Ø., and Austrheim, G.: Long-Term Increase in Aboveground Carbon Stocks Following Exclusion of Grazers and Forest Establishment in an Alpine Ecosystem, Ecosystems, 17, 1138-1150, doi:10.1007/s10021-014-9784-2, 2014.

Tasser, E., Walde, J., Tappeiner, U., Teutsch, A., and Noggler, W.: Land-use changes and natural reforestation in the Eastern Central Alps, Agr. Ecosyst. Environ., 118, 115-129, 2007.

Wilmking, M., Harden, J., and Tape, K.: Effect of tree line advance on carbon storage in NW Alaska, J. Geophys. Res.-Biogeo., 111, G02023, doi:10.1029/2005jg000074, 2006. 